\title{
Distribution and future projections for Schinopsis brasiliensis Engler (Anacardiaceae) in the semi-arid region of Brazil
}

\section{Carlos Antônio Belarmino Alves, ${ }^{1,2, *}$, Arliston Pereira Leite $^{2}$, João Everthon da Silva Ribeiro ${ }^{3}$, Natan Medeiros Guerra $^{4}$, Suellen da Silva Santos ${ }^{2}$, Ramon Santos Souza², Thamires Kelly Nunes Carvalho ${ }^{2}$, Camilla Marques de Lucena $^{2,5}$, Andrea Maia Fernandes de Araújo Fonseca ${ }^{2}$, João Alberto Lins Filho ${ }^{2}$, Jacob Silva Souto ${ }^{6}$ and Reinaldo Farias Paiva de Lucena ${ }^{2}$}

\footnotetext{
${ }^{1}$ State University of Paraíba. Campus III. Guarabira-PB, Brazil. E-mail: c_belarminoalves@hotmail.com.

${ }^{2}$ Ethnobiology and Environmental Sciences Laboratory. Department of Systematics and Ecology. Exact and Natural Sciences Center. Federal University of Paraíba, João Pessoa-PB, Brazil (CEP 58051-900).

${ }^{3}$ Postgraduate Program in Agronomy. Federal University of Paraíba. Agrarian Sciences Center. Campus II. Areia-PB, Brazil.

${ }^{4}$ Postgraduate Program in Phytotechnics. Federal Rural University of the SemiArid. Mossoró-RN, Brazil.

${ }^{5}$ Higher Education Institute of Paraíba - UNIESP. Internationalization Coordination. Cabedelo-PB, Brazil.

${ }^{6}$ Academic Unit of Forest Engineering. Federal University of Campina Grande. Patos-PB, Brazil.
}

\begin{abstract}
The advanced degradation and desertification processes, resulting from the anthropization of the semi-arid region of Brazil has led to an increasing need for research on the status of the occurrence of plant species. Schinopsis brasiliensis Engler, popularly known as "barauna", is recognized both for its exuberance and the use of its wood for different purposes. This species occurs in the Northeast and Midwest regions of Brazil and can be found in the Cerrado and Caatinga phytogeographic domains. This study aimed to analyze the local and regional distribution and abundance of $S$. brasiliensis in six municipalities in different regions of Paraíba State, as well as to perform the current and predictive modeling of the ecological niche of this species in the northeast region of Brazil, considering bioclimatic variables. On a state scale, this research was conducted in six rural communities, previously selected from studies already carried out by the Ethnobiology and Environmental Sciences Laboratory of the Federal University of Paraíba. On a regional scale, current and predictive modeling of the species' ecological

Received

September 29, 2020

Accepted

November 03, 2020

Available online November 05, 2020

Released

December 31, 2020

Full Text Article

ISSN 2359-1412/RBGAS-2020-01015/2020/7/17/21/1361
\end{abstract}

Rev. Bras. Gest. Amb. Sustent.

http://revista.ecogestaobrasil.net 
niche was used, considering bioclimatic variables, based on data obtained from the WorldClim database (www.worldclim.org). The data showed a heterogeneous distribution in the populations of S. brasiliensis. The high number of adult specimens may indicate low resource extraction. Climate change, in different scenarios, does not significantly affect the distribution of the study species in the Northeastern Region of Brazil.

Keywords: Availability; Climate change; Dry forests.

Resumo. Distribuição e projeções futuras de Schinopsis brasiliensis Engler (Anacardiaceae) na região semiárida do Brasil. 0 avanço dos processos de degradação e desertificação, decorrentes da antropização da região semiárida do Brasil têm levado a uma necessidade crescente de pesquisas sobre o estado e ocorrência das espécies vegetais. A espécie Schinopsis brasiliensis Engler, popularmente conhecida como "baraúna", é reconhecida tanto pela exuberância quanto pelo uso de sua madeira para diversos fins. Esta espécie ocorre nas Regiões Nordeste e Centro-Oeste do Brasil, e pode ser encontrada nos domínios fitogeográficos do Cerrado e da Caatinga. Este estudo teve como objetivo analisar a distribuição local e regional, e a abundância de $S$. brasiliensis em seis municípios de diferentes regiões do Estado da Paraíba, bem como realizar a modelagem atual e preditiva do nicho ecológico desta espécie na Região Nordeste do Brasil, considerando variáveis bioclimáticas. Em escala estadual, esta pesquisa foi realizada em seis comunidades rurais, previamente selecionadas a partir de estudos já realizados pelo Laboratório de Etnobiologia e Ciências Ambientais da Universidade Federal da Paraíba. Em escala regional, foi utilizada a modelagem atual e preditiva do nicho ecológico da espécie, considerando variáveis bioclimáticas, com base em dados obtidos no banco de dados WorldClim (www.worldclim.org). Os dados mostraram uma distribuição heterogênea nas populações de $S$. brasiliensis. $O$ alto número de espécimes adultos pode indicar baixa extração de recursos. As mudanças climáticas, em diferentes cenários, não afetam significativamente a distribuição da espécie em estudo na Região Nordeste do Brasil.

Palavras-chave: Disponibilidade; Mudanças climáticas; Florestas secas.

\section{Introduction}

The Northeastern Region of Brazil has an area of approximately 1,554,292 km², which is covered by a semi-arid domain of about $877,317 \mathrm{~km}^{2}$ (IBGE, 2011), occupying $56.44 \%$ of the region and accounting for 25 million people (MMA, 2009). This region comprises the Caatinga ecosystem $\left(912.529 \mathrm{~km}^{2}\right)$, which is inhabited by approximately 
28.6 million people, mostly in the rural area, who relate to 3,150 species of plants found in this ecosystem (Silva et al., 2017).

Schinopsis brasiliensis Engler is one of these species, popularly known as "barauna", which stands out both for its exuberance and beauty and its numerous applications. This species occurs in the northeastern states of Brazil, except in Maranhão, as well as in the Midwest region, recorded in the Federal District, Goiás, Mato Grosso, and Mato Grosso do Sul and found in the Cerrado and Caatinga phytogeographic domains (Kiill et al. 2005, Luz et al., 2019).

This species has already been used in the leather tanning industry because of the high content of tannins in the cell walls of its lignified tissues (bark and inner bark) (Kiill and Lima, 2011), which may have led to a decrease in its populations in semi-arid vegetation areas, contributing to its vulnerability condition.

According to ethnobotanical studies, S. brasiliensis is considered one of the most versatile plants in the semi-arid region of Brazil, recorded in the literature for different purposes in several categories of use, such as domestic constructions (door, window, beams, rafters, and slats), rural constructions (portress/gate, fence posts, and stakes), fuel (firewood and charcoal), technology (furniture and tool handles), and other timber and non-timber uses (Pereira et al., 2003; Trovão et al., 2004; Ferraz et al., 2006; Sousa, 2006; Lucena et al., 2008; Albuquerque et al., 2009; Lucena et al., 2012a,b; Alves et al., 2009; Silva et al., 2014).

Martins et al. (2003) found S. brasiliensis in uniform groups. Santana (2009), Mendes Júnior and Drumond (2009) evidenced a common occurrence of clusters in areas of Caatinga, where the abundance of this species appears clustered or with a tendency to form clusters. Mendes Júnior and Drumond (2009) explain this is a strategy of caatinga species to establish a large number of specimens in areas that have suffered some disturbance, even climatic. These authors emphasize that classification and studies recording few specimens in ecological surveys should be carefully analyzed.

However, in certain environments, the number of specimens has decreased. According to Calixto Júnior and Drumond (2014), a large part of the Caatinga has already suffered clear-cutting, which has caused a decrease in species diversity and the number of specimens in the last 30 years, including barauna. These authors also recorded the existence of a recovering population in fragments of Caatinga, and that when these areas were compared with other preserved areas, it was possible to observe both physiognomic and structural differences, evidencing these fragments have not yet reached a stage of ecological development similar to those in better conservation status.

The advanced degradation and desertification, as well as other environmental and anthropogenic changes, are other processes that affect the occurrence of $S$. brasiliensis in the semi-arid region of Brazil (Garda, 1996; Fernandes, 2002; Maia, 2004; Oyama and Nobre, 2004; MMA, 2008; COSTA et al., 2009). From this point of view, studies aimed at understanding the impacts of climatic events and changes in habitats on the distribution of plant species, such as the research by Butt and Gallagher (2018), have become more frequent and necessary so that more detailed and significant answers can be obtained.

Given the above, this study aimed to assess the local and regional distribution and abundance of $S$. brasiliensis in six municipalities in different regions of Paraíba, in addition to performing current and predictive modeling of the species' ecological niche in the northeast region of Brazil, considering bioclimatic variables.

\section{Material and methods}

\section{Design for the State of Paraíba}

Study area. This research was conducted in six rural communities in different areas of the semi-arid region of Paraíba, northeastern Brazil, as follow: São Francisco in

Rev. Bras. Gest. Amb. Sustent., 2020, vol. 7, n. 17, p. 1361-1378. 
the municipality of Cabaceiras, Santa Rita in Congo, Pau d'Arco in Itaporanga, Coelho in Remígio, Várzea Alegre in São Mamede, and Capivara in Solânea, distributed between the Sertaneja Depression and the Borborema Plateau (Figure 1). These areas were selected from preliminary information obtained by researchers (Guerra et al., 2012; Leite et al., 2012; Lucena et al., 2012; Pedrosa et al., 2012; Sousa et al., 2012; Lucena et al., 2013; Lucena et al., 2014; Silva et al., 2014; Ribeiro et al., 2014) of the Ethnobiology and Environmental Sciences Laboratory (LECA/UFPB).
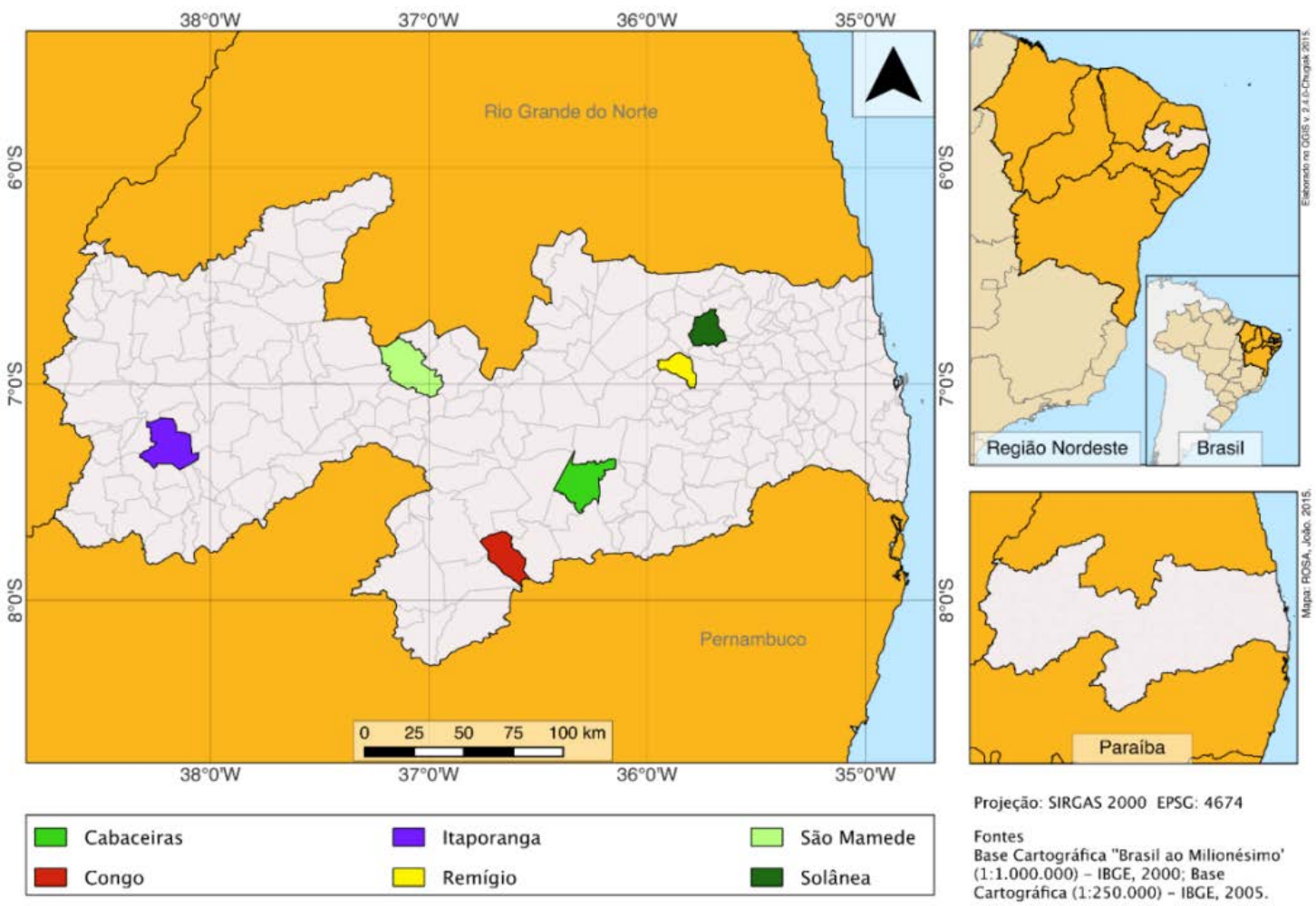

Figure 1. Geographic location of the municipalities of Cabaceiras, Congo, Itaporanga, Remígio, São Mamede, and Solânea (Paraíba, northeastern Brazil). Map by Ramon Souza.

The Municipality of Cabaceiras $\left(7^{\circ} 29^{\prime} 20^{\prime \prime} \mathrm{S}\right.$ and $\left.36^{\circ} 17^{\prime} 14^{\prime \prime} \mathrm{W}\right)$ is located in the Borborema Mesoregion and Cariri Oriental Microregion, in the Borborema Plateau. It covers an area of $452,922 \mathrm{~km}^{2}$, at $400 \mathrm{~m}$ altitude, with a "BSh" climate (semi-arid hot), mean annual temperature above $20^{\circ} \mathrm{C}$, and the lowest rainfall in Brazil, less than $300 \mathrm{~mm}$ per year (IBGE, 2010).

The Municipality of Congo $\left(07^{\circ} 47^{\prime} 49^{\prime \prime} \mathrm{S}\right.$ and $36^{\circ} 39^{\prime} 36^{\prime \prime} \mathrm{W}$ ) is located in the Borborema Mesoregion and Cariri Ocidental Microregion, in the Borborema Plateau, covering an area of $333,471 \mathrm{~km}^{2}$, at an altitude of $480 \mathrm{~m}$. The climate in the region is semiarid tropical, with summer rains ("Aw"), a mean temperature around $26^{\circ} \mathrm{C}$, and a mean annual rainfall above $400 \mathrm{~mm}$ (IBGE, 2010).

The Municipality of Itaporanga $\left(7^{\circ} 18^{\prime} 14^{\prime \prime} \mathrm{S}\right.$ and $\left.38^{\circ} 09^{\prime} 00^{\prime \prime} \mathrm{W}\right)$ is located in the Sertão Mesoregion and Piancó Valley Microregion, in the Sertaneja Depression, covering an area of $468,060 \mathrm{~km}^{2}$, at an altitude of $191 \mathrm{~m}$. The climate in the region is hot semi-arid 
("Aw"), with a mean temperature above $23 \mathrm{C}$, short rainy season, high intensity and short duration rains, and mean annual rainfall above $500 \mathrm{~mm}$ (IBGE, 2010).

The Municipality of Remígio ( $06^{\circ} 54^{\prime} 10^{\prime \prime} \mathrm{S}$ and $35^{\circ} 50^{\prime} 02^{\prime \prime} \mathrm{W}$ ) is in the Agreste Mesoregion and Curimataú Ocidental Microregion, in the Borborema Plateau. It covers an area of $180,897 \mathrm{~km}^{2}$, at an altitude of $593 \mathrm{~m}$, with a rainy tropical climate and dry summer ("Aw"), a mean temperature of $22^{\circ} \mathrm{C}$, and annual rainfall above $700 \mathrm{~mm}$ (IBGE, 2010).

The Municipality of São Mamede ( $6^{\circ} 55^{\prime} 37^{\prime \prime}$ S and $37^{\circ} 05^{\prime} 45^{\prime \prime} \mathrm{W}$ ) is in the Sertão Paraibano Mesoregion and Seridó Ocidental Microregion, in the Sertaneja Depression. This municipality covers an area of approximately $530,728 \mathrm{~km}^{2}$, at an altitude of around $263 \mathrm{~m}$, with a "BSh" climate (hot semi-arid), summer rains, mean annual temperature of $28{ }^{\circ} \mathrm{C}$, and mean annual rainfall of $700 \mathrm{~mm}$ (IBGE, 2010).

The Municipality of Solânea $\left(06^{\circ} 46^{\prime} 40^{\prime \prime} \mathrm{S}\right.$ and $\left.35^{\circ} 41^{\prime} 49^{\prime \prime} \mathrm{W}\right)$ is located in the Agreste Mesoregion and Curimataú Oriental Microregion, in the Borborema Plateau, covering an area of $232,096 \mathrm{~km}^{2}$, at an altitude of $626 \mathrm{~m}$. The climate in the region is rainy tropical with dry summer ("As"), mean annual temperature of around $25^{\circ} \mathrm{C}$, and mean annual rainfall above $800 \mathrm{~mm}$ (IBGE, 2010).

Data collection and analysis. The local distribution of $S$. brasiliensis in the communities was recorded and mapped using the guided tour technique, which consists of interviewing local specialists (Bailey, 1994; Albuquerque et al., 2010). The tour consisted of a 24-hour walk along the physical perimeter of the communities in the six municipalities, totaling 144 hours.

To draw a map of local geographic distribution in each community, all specimens found were identified and mapped by recording their geographic coordinates, using a Garmin Oregon ${ }^{\circledR} 400$ t GPS.

Subsequently, the data obtained in each municipality was organized in Microsoft Excel ${ }^{\circledR}$ spreadsheets, calculating (1) the total amplitude, (2) number of classes, by the distribution of Sturges (Logarithm Rule), and (3) the amplitude of classes, according to the following equations, respectively:

$\mathrm{TA}=$ total amplitude; $\mathrm{MV}=$ the largest perimeter; $\mathrm{mv}=$ the smallest perimeter .

$\mathrm{NC}=$ number of classes; $\mathrm{N}=$ number of sampled specimens;

$\mathrm{AC}=$ amplitude of classes; $\mathrm{AT}=$ total amplitude; $\mathrm{NC}=$ number of classes.

After obtaining these data, the amplitude of classes was used in each data set of each municipality, establishing the classes in centimeters, between the smallest and the largest perimeters, with the necessary adjustments, preventing the meeting of classes (Sturges, 1926). Distribution graphs were drawn to show the frequency (Y-axis) and classes (X-axis), as well as the standard error, in which the mean standard error was used to determine the precision with which the sample mean estimates the population mean.

For species identification, plant material was collected, processed in the field, and taken to the Ethnoecology Laboratory for treatment. The material (Registration No. 
17.255) was later identified and deposited in the Herbarium "Jayme Coelho de Morais" (EAN) of the Federal University of Paraíba (Agrarian Sciences Center - Campus II).

For the spatial distribution, in addition to drawing a map, Pearson's correlation (r) and determination coefficient $\left(\mathrm{R}^{2}\right)$ were calculated for the number of specimens, mean height, and mean perimeter, for the species in all study communities.

\section{Design for the Northeast Region}

Species occurrence data collection. Occurrence areas of Schinopsis brasiliensis were obtained from the Global Biodiversity Information Facility-GBIF (https://www.gbif.org), iNaturalist (https://www.inaturalist.org) and Integrated Digitized Biocollections-iDigBio (https://www.idigbio.org), using the $\mathrm{R}$ software to search for occurrence data, adjust one point per cell of $1 \mathrm{~km}^{2}$, and remove duplicates. This procedure was performed to obtain the species distribution in northeastern Brazil, resulting in 548 specimens.

Environmental variables. The database required for the modeling consisted of 19 bioclimatic (Hijmans et al., 2005) and 1 biophysical (elevation) variables, with a spatial resolution of 30 arc seconds (approximately $1 \mathrm{~km}^{2}$ ), obtained from the WorldClim database (www.worldclim.org). The current climatic data correspond to the interpolated database for 1960-1990. The observation of representative scenarios of carbon dioxide concentrations (RCPs), optimistic (RCP4.5), and pessimistic (RCP8.5), derived from the HadGEM2-ES model, makes possible the formulation of a predictive niche map that demonstrates a possible species distribution until 2050 (mean forecast for 2041-2060). These were the most recent climate projections of the Global Circulation Models (GCMs) used in the fifth IPCC report (CMIP5).

To reduce multicollinearity, highly correlated variables $(r \geq 0.7$ Pearson's correlation coefficient) were excluded (Graham, 2003). This decrease resulted in the inclusion of 8 predictor variables, as follow: mean annual temperature (Bio1), isothermalism (Bio3), annual thermal amplitude (Bio7), annual rainfall (Bio12), rainfall in the driest month (Bio14), rainfall seasonality (Bio15), rainfall in the warmest trimester (Bio18), and rainfall in the coldest trimester (Bio19).

The ecological niche modeling was performed in the R software using the MaxEnt algorithm (Phillips et al., 2006) in the dismo package (Hijmans et al., 2017). This algorithm worked better with small samples in comparison with other modeling methods (Pearson et al., 2007; Kumar and Stohlgren, 2009). The models of our research were run using the Bootstrap method for 100 repetitions, from which $75 \%$ and $25 \%$ of the data were selected for training and testing the model, respectively (Phillips, 2008). Using k-fold partitioning, 10,000 random background points were created. The Jackknife test was performed to determine the importance of the variables (Figure 2). The area under the curve (AUC), or ROC curve, was used to evaluate the model's performance. The AUC values range from 0-1 (Fielding and Bell, 1997). An AUC up to 0.50 indicates the model had no better performance in comparison with a random model, whereas 1.0 indicates perfect discrimination (SWETS, 1988). 


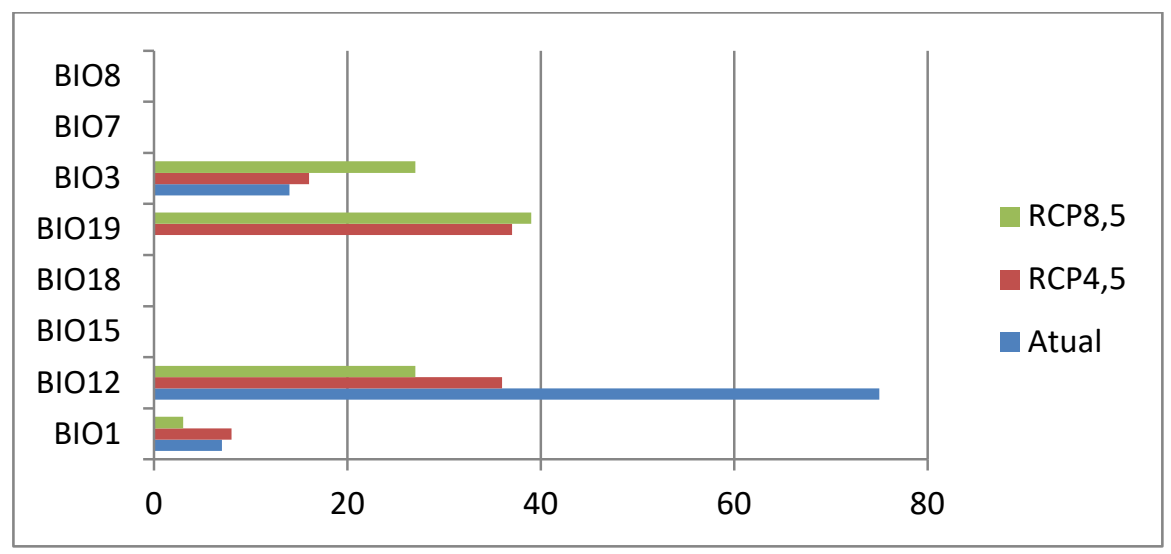

Figure 2. Evaluation of the relative importance of environmental variables using the Jackknife test.

For later exhibition and analysis, predicting the presence of species (0-1), variables were reclassified in the QGIS software, version 3.4 (QGIS Development Team, 2019), based on the classification proposed by Yang et al. (2013), into five potential classes: unsuitable habitat (0-0.2); barely suitable habitat (0.2-0.4); suitable habitat (0.4-0.6); highly suitable habitat (0.6-0.8); very highly suitable habitat (0.8-1.0). For each model, distribution area was calculated and binary values of presence (1) and absence (0) were obtained, using a cut-off threshold to maximizes the sum between sensitivity (true positives) and specificity (true negatives), according to the test data (MaxSS) (Jiménez-Valverde and Lobo, 2007; Liu et al., 2013).

\section{Results and discussion}

\section{Spatial distribution in regions of Paraíba}

After completing the 144 hours of guided tour in the six study communities, 624 specimens of $S$. brasiliensis were recorded (Table 1). No specimen was found in Várzea Alegre (São Mamede).

Sixty-four specimens were recorded in São Francisco (Figure 3), with a minimum height of $3 \mathrm{~m}$ and a maximum height of $18 \mathrm{~m}$. All plants were grouped into classes, the smallest of $25 \mathrm{~cm}$ and the largest of $233 \mathrm{~cm}$. The majority (64.06\%) were grouped into two perimeter classes with ranging from $55 \mathrm{~cm}$ to $114 \mathrm{~cm}$, showing a possible adult population. No plant with a perimeter $<25 \mathrm{~cm}$ was recorded, which may indicate the absence of young specimens and seedling recruitment, soon leading to the existence of an old population, which will be more susceptible to anthropogenic activities and local extinction process.

Based on the coefficients of variation [CV (\%)], height, and perimeter, it can be suggested that the species has a heterogeneous pattern, indicating the presence of specimens in various classes, which can be a good finding, considering the ecological succession process, which may indicate a recovery process of $S$. brasiliensis and recruitment of its young specimens.

The determination of these parameters with the number of specimens is very important since several characteristics of the target vegetation can be inferred, such as management and preservation and conservation intensities (Alcoforado-Filho et al., 2003; Herrera et al., 2009; Longhi et al., 2013). Based on this importance presented by the aforementioned literature, the data obtained in our study are useful and relevant for future actions aimed at the management and conservation of this important species in the semi-arid region of Brazil. 
Table 1. Total number of specimens of Schinopsis brasiliensis Engler, recorded during a guided tour in six rural communities in the semi-arid region of Paraíba, northeastern Brazil, and their mean height \pm standard deviation $(\mathrm{m})$, mean perimeter \pm standard deviation $(\mathrm{cm})$, and respective coefficients of variation [CV (\%)].

\begin{tabular}{llccccc}
\hline Município & Comunidade & $\begin{array}{c}\text { Indivíduo } \\
\text { s }\end{array}$ & $\begin{array}{c}\text { Altura } \\
\text { média (m) }\end{array}$ & $\begin{array}{c}\text { C.V. } \\
\mathbf{( \% )}\end{array}$ & $\begin{array}{c}\text { Perímetro médio } \\
\text { (cm) }\end{array}$ & $\begin{array}{c}\text { C.V. } \\
\text { (\%) }\end{array}$ \\
\hline Cabaceiras & São Francisco & 64 & $10,63 \pm 2,96$ & 27,84 & $99,23 \pm 37,28$ & 37,56 \\
Congo & Santa Rita & 243 & $9,73 \pm 3,12$ & 32,06 & $72,52 \pm 46,34$ & 63,89 \\
Itaporanga & Pau d'Arco & 43 & $5,87 \pm 2,89$ & 49,23 & $31,90 \pm 17,21$ & 53,94 \\
Remígio & Coelho & 116 & $11,34 \pm 3,49$ & 30,77 & $103,45 \pm 52,14$ & 50,40 \\
São Mamede & Várzea Alegre & - & - & - & - & - \\
Solânea & Capivara & 158 & $9,46 \pm 4,11$ & 43,44 & $61,41 \pm 43,48$ & 70,80 \\
\hline
\end{tabular}

From the information on the distribution, height, and perimeter of the specimens, Pearson's correlation between such variables can be shown to explain some correlations between the populations of $S$. brasiliensis in the study communities (Table 2).

Table 2. Pearson's correlation for the number of specimens of Schinopsis brasiliensis Engler, and their mean height and mean perimeter in six communities in the semi-arid region of Paraíba, northeastern Brazil.

\begin{tabular}{lccc}
\hline & Número de Indivíduos & Altura média (m) & Perímetro médio (m) \\
\hline Indivíduos registrados & - & 0,65 & 0,50 \\
Altura média (m) & - & 0,95 \\
Perímetro médio (m) & & & - \\
\hline
\end{tabular}

The number of specimens positively related to both mean height and mean perimeter with coefficients of determination of $\mathrm{R}^{2}=41.93 \%$ and $\mathrm{R}^{2}=24.81 \%$, respectively, indicating that, although it is a mean correlation, in some cases, probably most of the specimens of a population have greater height and diameter.

The mean height also positively correlated with the mean perimeter, with a coefficient of determination $\mathrm{R}^{2}=90.69$, showing that, for being a high correlation, when the mean height increases, the mean perimeter also increases and thus, possibly, the perimeter and the height tend to be proportional in relatively old populations. Similar parameters are found in other species, which, after primary growth ceases, tend to develop only their secondary growth, causing height to be proportional in adult specimens (Lima et al., 2015).

The local distribution maps of $S$. brasiliensis with its classification into perimeter classes are shown in Figures 4 and 5.

Silva et al. (2014) conducted a phytosociological study in the same region and communities by allocating plots; however, they recorded no specimen of $S$. brasiliensis. Based on our research and that by Silva et al. (2014), it is possible to suggest studies aimed at mapping a specific species. The phytosociological surveys carried out by these authors may not be suitable because they allocated the plots or transects in very specific areas, failing to record specimens in other areas, where the guided tour could be a good complementary alternative, as can be seen through the 64 specimens recorded. 


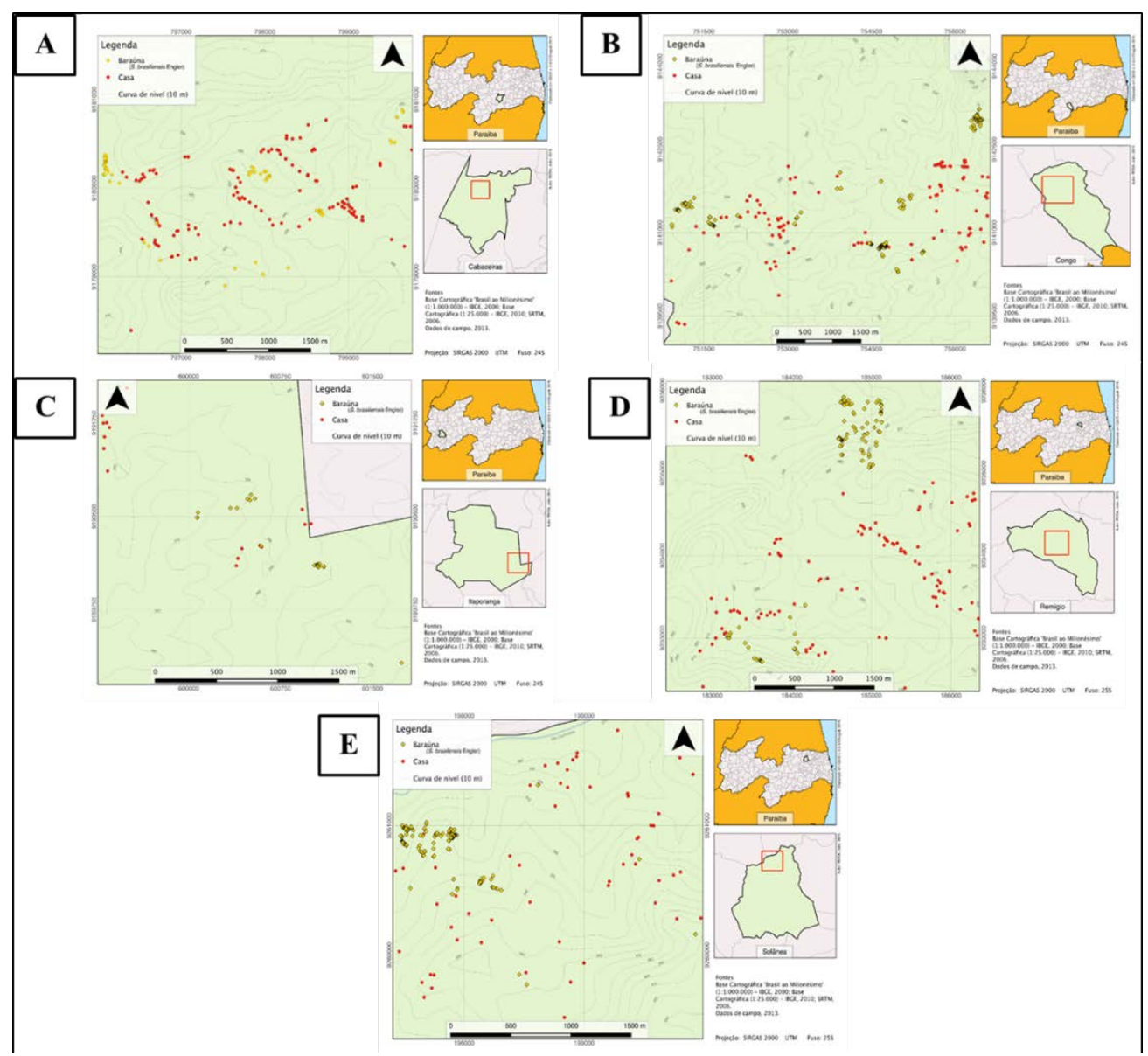

Figure 4. Spatial distribution of specimens of Schinopsis brasiliensis Engler in communities in the State of Paraíba, Northeastern Brazil. A - São Francisco (Municipality of Cabaceiras); B - Santa Rita (Congo); C - Pau d'Arco (Itaporanga); D - Coelho (Remígio); E - Capivara (Solânea).

Apgaua et al. (2014), studying tree communities through plots in dry forest remnants, recorded six specimens of $S$. brasiliensis. Oliveira et al. (2009), studying plots in four forest remnants in mountains in the Cariri Oriental microregion in the municipalities of Caturité and Boqueirão (Paraíba) found only 32 specimens. Both studies recorded a smaller number of specimens in comparison with our research, excluding the community of Várzea Alegre, where no specimen was found.

São Francisco was one of the communities with the smallest number of specimens found during the guided tour, the second one in terms of specimens recorded, distributed in clusters (Figure 4A). An interesting fact is that some preserved specimens were found in private properties or yards. This preservation is intended for a potential resource, i.e., such specimens are a resource to be used in emergency times. These populations are located in small fragments of secondary forest, comprising areas that were used for agropastoral purposes several years ago and afterward abandoned, starting a recovery process, according to the locals. 


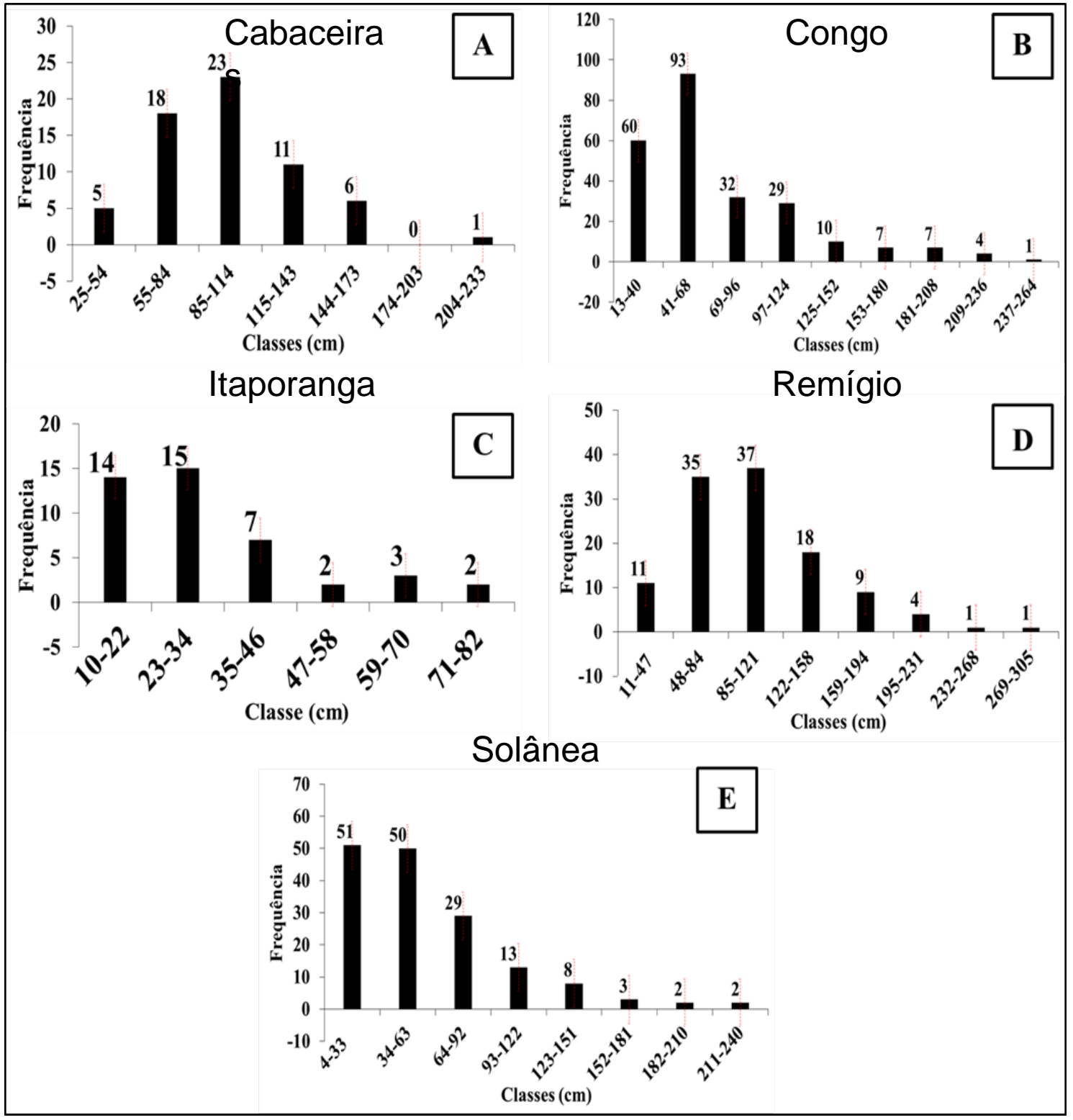

Figure 5. Classification of specimens of Schinopsis brasiliensis Engler in communities in the state of Paraíba, northeastern Brazil. A - São Francisco (municipality of Cabaceiras); B - Santa Rita (Congo); C - Pau D'Arco (Itaporanga); D - Coelho (Remígio); E - Capivara (Solânea).

A total of 243 specimens were recorded in Santa Rita (Figure 5B), which had a minimum height of $1 \mathrm{~m}$ and a maximum height of $22 \mathrm{~m}$. All of them were grouped into classes, a minimum of $13 \mathrm{~cm}$ and a maximum of $264 \mathrm{~cm}$. The $41-68 \mathrm{~cm}$ and $69-124 \mathrm{~cm}$ perimeter classes accounted for $38.27 \%$ and $25.10 \%$ of specimens, respectively. These two classes represent $63.37 \%$ of the total recorded population. Based on these perimeters, it can be assumed that the vast majority of the specimens in this community are adults (Figure 5).

Ferreira (2011), in a vegetation survey in the Cariri Paraibano, recorded 20 specimens of $S$. brasiliensis. Lima (2007), analyzing distribution patterns of woody species in the Caatinga in a single plot of $100 \times 100 \mathrm{~m}$, in the Brazilian semi-arid region, found 6 specimens. These differences in the number of specimens may be related to the water 
needs in each region, in addition to the fact that, in protected areas or private properties, the species is found in a high number and clustered. This clustering strategy is quite common in caatinga species because when they are established in this way their growth and development become easier (Lorenzi and Matos, 2002; Silva et al., 2009). This pattern was observed in practically all the study communities.

Costa et al. (2009) argue that water availability can be a determining factor in the distribution of species. Other authors add that the greater or lesser number of species and their distribution are responses to a set of factors such as topographical condition, successional class, soil depth and permeability, and non-availability of water; however, the lack of water is the main limiting factor (Amaral et al., 2012).

Santa Rita stood out for having the highest number of specimens recorded during the guided tour, which were found distributed in clusters in areas of difficult access, such as mountains, dense vegetation, and private properties, away from main roads (Figure 4B). Kaminski et al. (2013), in research in the central region of Pernambuco, found that the arboreal vegetation is restricted to small fragments in valleys on the edges of intermittent water bodies, where the soil is visually sandier and deeper, and in areas more distant from living beings.

The smallest number of specimens found during the guided tour was recorded in the Community of Pau d'Arco, only 43 (Figure 4C), with a minimum and a maximum height of $1 \mathrm{~m}$ and $12 \mathrm{~m}$, respectively. All specimens were grouped into classes, a minimum of $10 \mathrm{~cm}$ and a maximum of $82 \mathrm{~cm}$. The majority (51.62\%) were classified into the $23-46 \mathrm{~cm}$ perimeter class, suggesting the occurrence of an adult population, and $32.56 \%$ were classified into the $12-24 \mathrm{~cm}$ perimeter class (Figure 5C). This shows that, although the majority of specimens have high perimeters, which can indicate an adult and old population, almost $1 / 3$ of the specimens are young, showing that this population may be in an ecological regeneration process.

The situation observed in Pau D'Arco can be understood based on the literature data, which show that most of the areas of Caatinga have already suffered anthropogenic disturbance for having species with quality and resistant wood; therefore, the specimens tend to be younger (Kaminski et al., 2013). Leite et al. (2012), in this same study area, using phytosociological survey plots, recorded only one specimen of $S$. brasiliensis.

Souza et al. (2012), studying forest fragments in Minas Gerais, observed that most of the arboreal specimens, for being denser, tend to be classified into the first diameter classes, being considered younger specimens. The ecological groups of initial and late secondary species have a high concentration of specimens in the smallest, indicating high regeneration due to the high number of specimens and, consequently, a promising advance for mature successional stages (Cabral, 2014).

Most of the specimens recorded in Pau D'Arco were distributed in clusters, in areas of difficult access, within forests and private properties, away from main roads and residences.

Regarding the community of Coelho, 116 specimens were recorded, with a minimum height of $3 \mathrm{~m}$ and a maximum height of $20 \mathrm{~m}$. The specimens were grouped into classes, a minimum of $11 \mathrm{~cm}$ and a maximum of $305 \mathrm{~cm}$. The majority (62.06\%) were classified into the $48-121 \mathrm{~cm}$ perimeter class, which may indicate a late adult population (Figure 5D).

Although no information on the occurrence and distribution of $S$. brasiliensis was recorded in Remígio for comparison with specialized literature, a discussion can be made based on the data recorded in the other study communities. Coelho was one of the communities where specimens of $S$. brasiliensis were most found, with a considerable number. This may be justified by the cultural and economic regional context, as some people said in informal conversations not to use this species, contributing in a certain way to the maintenance of its local populations.

Rev. Bras. Gest. Amb. Sustent., 2020, vol. 7, n. 17, p. 1361-1378. 
The fact that the vast majority of the specimens have had a large perimeter and that few young and regenerating species have been recorded can be explained by several environmental conditions, such as climate change, and changes in seasonality and water regime dynamics, as well as the lack of conditions for environmental recovery of degraded areas.

Concerning Capivara, 158 specimens were found (Figure 4E). This community was the second largest in the number of specimens recorded during the guided tour, which had a minimum height of $2.0 \mathrm{~m}$ and a maximum height of $23.0 \mathrm{~m}$. All specimens were grouped into perimeter classes (a minimum of $4 \mathrm{~cm}$ and a maximum of $240 \mathrm{~cm}$ ). Half of them (50\%) were classified into the $34-92 \mathrm{~cm}$ class. The $4-33 \mathrm{~cm}$ class accounted for $32.27 \%$ specimens, corresponding to approximately $1 / 3$ of the total population. Similar to what was observed in Itaporanga, the results obtained in Solânea are important because they may indicate that the population is in a recovery process, justified by the high number of young specimens (Figure 5E).

Durães et al. (2014), studying remaining areas of Caatinga, using the free walking method on the affluent banks of the São Francisco River in Montes Claros (Minas Gerais, Brazil) found only 7 specimens of $S$. brasiliensis. On the other hand, Barbosa et al. (2012), recorded no specimen in their research in 40 plots in the municipality of Arcoverde (Pernambuco, Brazil).

Comparative studies on species diameters when relating degraded areas to nondegraded areas showed that the number of young specimens in the first area is proportionally higher than in the second one, indicating some type of disturbance (Ferraz, 2011). Possibly, the study area (Capivara) has suffered disturbance for a long time and today, due to the residents' awareness, it is more preserved, as the uniformity pattern of specimens distributed in the classes is equivalent.

\section{Occurrence and predictive modeling}

The current occurrence and the climate scenarios (RCP4.5 and RCP85) (Figure 6A) indicate the areas most likely to have niche characteristics of $S$. brasiliensis. In this case, there is a small decrease in its occurrence in both climate scenarios, mainly in the state of Bahia. Maranhão is the only state that had no occurrence of this species.

Regarding predictive modeling (Figure 7B), it is possible to identify a small decrease in highly suitable habitat (0.6-0.8) and very highly suitable habitat $(0.8-1.0)$ in eastern Bahia, and a slightly more significant decrease in suitable habitat (0.4-0.6) in eastern Piauí, central-eastern Ceará, and southern Bahia culminating in the expansion of unsuitable habitat (0-0.2) and barely suitable habitat (0.2-0.4) in those regions.

The slight decrease in suitable habitat in the pessimistic climate scenario can be interpreted in a positive way considering the possibility of species fragility to the consequences of climate change. It is worth mentioning this fact means that, even if there is an extreme change in bioclimatic variables that influence the niche conditions for the occurrence of $S$. brasiliensis, it will probably occur in areas where it can be found under the current conditions.

This can also be an auxiliary answer to understand the environmental condition of the species' occurrence areas, which may mean that even in a pessimistic scenario, the ecosystem will still be able to support a species of an advanced level of ecological succession such as $S$. brasiliensis. Nevertheless, statements like this can only be confirmed through more in-depth ecological and predictive studies that can diagnose the species vulnerability (Gallagher et al., 2018). 


\section{Final considerations}

Schinopsis brasiliensis Engler was recorded in different perimeter classes and, consequently, different ages, heights, and locations, evidencing the heterogeneity of its populations in different regions of the state of Paraíba. However, adult specimens are predominant, positively indicating a possible decrease in the extraction of plant resources, especially by local human populations. Possibly, considering the decreased pressure on this species, it will tend to regenerate naturally, if larger-scale disturbances occur.

The fact that no specimen was found in Várzea Alegre during the guided tour does not indicate the study species is locally extinct; specimens may be distributed in areas of difficult access, so they were not found.

The regional analysis showed a slight decrease in the populations of $S$. brasiliensis in its occurrence area, which may indicate that climate changes do not significantly interfere with its distribution.

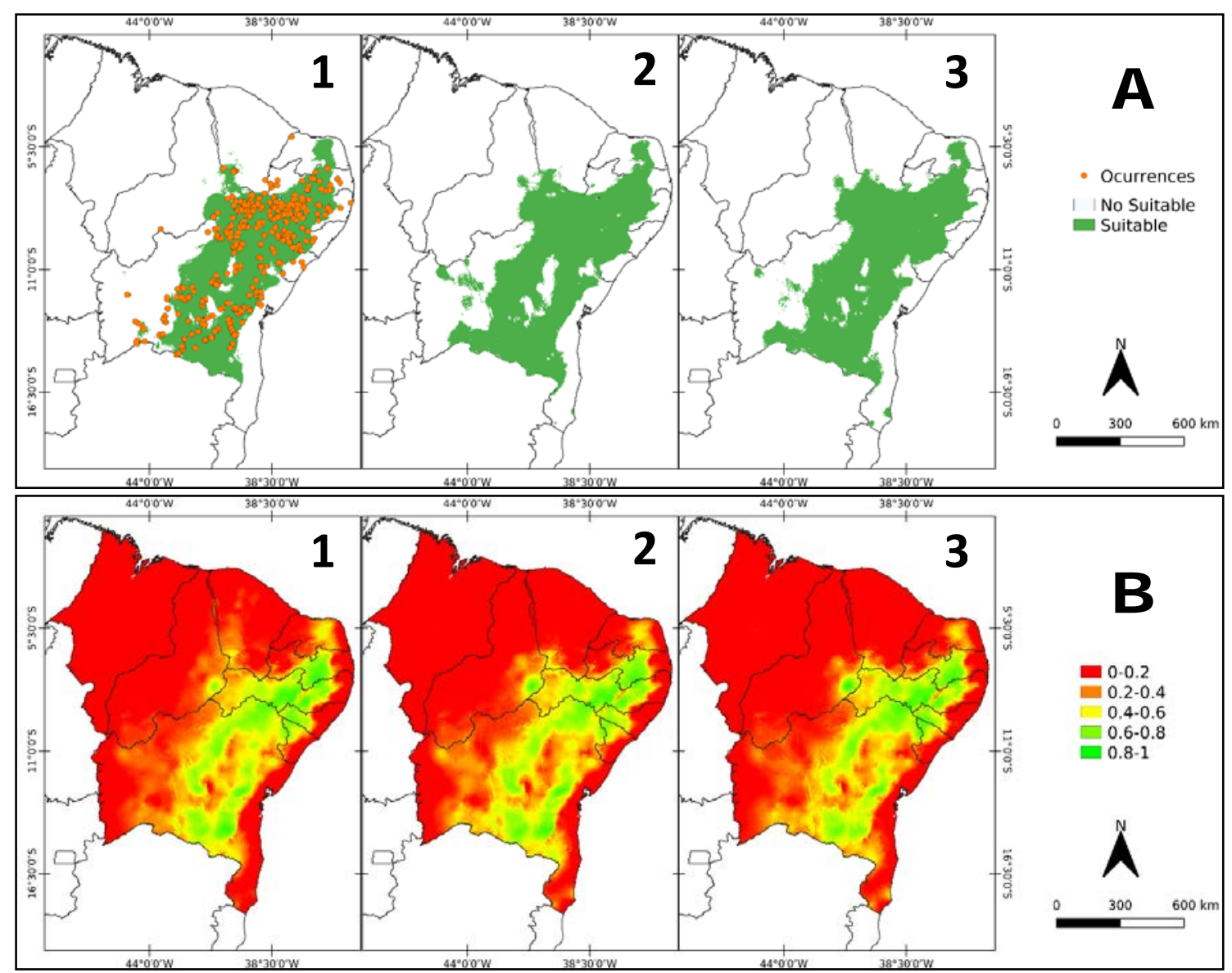

Figure 6. Distribution map of $S$. brasiliensis in northeastern Brazil. Where: A = current distribution; $\mathrm{B}=$ predictive distribution; 1 = species distribution areas; 2 = distribution according to the optimistic (RCP4.5) scenario; 3 = distribution according to the pessimistic (RCP8.5) scenario. 


\section{References}

Albuquerque, U. P.; Araujo, T. A. S.; Ramos, M. A.; Nascimento, V. T.; Lucena, R. F. P.; Monteiro, J. M.; Alencar, N.; Araújo, E. L. How ethnobotany can aid biodiversity conservation reflections on investigations in the semi-arid region of $\mathrm{NE}$ Brazil. Biodiversity and Conservation, v. 18, no. 1, p. 127-150, 2009. https://doi.org/10.1007/ s10531-008-9463-8

Albuquerque, U. P.; Sousa, T. A.; Soldati, G. T. O "retorno" das pesquisas etnobiológicas para as comunidades. In: Albuquerque, U. P.; Lucena, R. F. P.; Cunha, L. V. F. C. (Eds.). Métodos e técnicas na pesquisa etnobiológica e etnoecológica. Recife: Nupeea, 2010.

Alcoforado-Filho, F. G.; Sampaio, E. V. S. B.; Rodal, M. J. N. Florística e fitossociologia de um remanescente de vegetação caducifólia espinhosa arbórea em Caruaru, Pernambuco. Acta Botanica Brasilica, v. 17, no. 2, p. 287-303, 2003. https://doi.org/10.1590/S010233062003000200011

Alves, R. R. N.; Mendonça, L. E. T.; Confessor, M. V. A.; Vieira, W. L. S; Lopez, L. C. S. Hunting strategies used in the semi-arid region of northeastern Brazil. Journal of Ethnobiology and Ethnomedicine, v. 5, n. 1, Article number 12, 2009. https://doi.org/10.1186/17464269-5-12

Amaral, G. C.; Alves, A. R.; Oliveira, T. M.; Almeida, K. N. S.; Farias, C. G. G.; Botrel, R. T. Estudo florístico e fitossociológico em uma área de transição Cerrado-Caatinga no Município de Batalha-PI. Scientia Plena, v. 8, no. 4, p. 1-5, 2012.

Apgaua, D. M. G.; Coelho, P. A.; Santos, R. M. D.; Santos, P. F.; Oliveira-Filho, A. T. D. Tree community structure in a seasonally dry tropical forest remnant, Brazil. Cerne, v. 20, no. 2, p. 173-182, 2014. https://doi.org/10.1590/01047760.201420021540

Bailey, K. Methods of social research. 4. ed. New York: The Free Press, 1994.

Barbosa, M. D.; Marangon, L. C.; Feliciano, A. L. P.; Freire, F. J.; Duarte, G. M. T. Florística e fitossociologia de espécies arbóreas e arbustivas em uma área de caatinga em Arcoverde, PE, Brasil. Revista Árvore, v. 36, no. 5, p. 851-858, 2012. https://doi.org/10.1590/S010067622012000500007

Cabral, G. A. L. Fitossociologia em diferentes estádios sucessionais de Caatinga Santa Terezinha-PB. Recife: Universidade Federal de Pernambuco, 2014. (Dissertação de mestrado).

Calixto-Júnior, J. T. C.; Drumond, M. A. Estudo comparativo da estrutura fitossociológica de dois fragmentos de Caatinga em níveis diferentes de conservação. Pesquisa Florestal Brasileira, v. 34, no. 80, p. 345-355, 2014.

Costa, T. C. C.; Oliveira, M. A. J.; Accioly, L. J. O.; Silva, F. H. B. B. Análise da degradação da caatinga no núcleo de desertificação do Seridó (RN/PB). Revista Brasileira de Engenharia Agrícola Ambiental, v. 13, supl., p. 961-974, 2009. https://doi.org/10.1590/ S1415-43662009000700020

Durães, M. C. O.; Sales, N. L. P.; D’Ângelo Neto, S.; Figueiredo, M. A. P. Levantamento florístico do estrato arbóreo de três fragmentos de floresta ciliar como subsídio à recomposição da vegetação do Rio Cedro, Montes Claros-MG. Ciência Florestal, v. 24, no. 1, p. 47-58, 2014. https://doi.org/10.5902/1980509813322

Fernandes, A. Biodiversidade da Caatinga. In: Araújo, E. L.; Moura, A. N.; Sampaio, E. S. B.; Gestinari, L. M. S.; Carneiro, J. M. T. (Eds.). Biodiversidade, conservação e uso sustentável da flora do Brasil. Recife: Imprensa Universitária, 2002. p. 42-44. 
Ferraz, J. S. Análise da vegetação de caatinga arbustivo-arbórea em Floresta, PE, como subsídio ao manejo florestal. Recife: Universidade Federal Rural de Pernambuco, 2011. (Tese de doutorado).

Ferraz, J. S. F.; Albuquerque, U. P.; Meunier, I. M. J. Valor do uso e estrutura da vegetação lenhosa às margens do Riacho do Navio, Floresta, PE, Brasil. Acta Botanica Brasilica, v. 20, p. 125-134, 2006. https://doi.org/10.1590/S0102-33062006000100012

Ferreira, N. E. S. Caracterização e análise socioeconômica da vegetação de caatinga em projetos de assentamento no cariri ocidental paraibano. Patos: Universidade Federal de Campina Grande, Patos, 2011. (Monografia de especialização).

Fielding, A. H.; Bell, J. F. A review of methods for the measurement of prediction errors in conservation presence/absence models. Environmental Conservation, v. 24, p. 38-49, 1997. https://doi.org/10.1017/S0376892997000088

Garda, E. C. Atlas do meio ambiente do Brasil. Brasília: Terra Viva, 1996.

Guerra, N. M.; Ribeiro, J. P. S.; Carvalho, T. K. N.; Pedrosa, K. M.; Félix, L. P.; Lucena, R. F. P. Usos locais de espécies vegetais nativas em uma comunidade rural no semiárido nordestino (São Mamede, Paraíba, Brasil). Revista de Biologia e Farmácia, v. especial, p. 184-210, 2012.

Graham, M. H. Confronting multicollinearity in ecological multiple regression. Ecology, v. 84, p. 2809-2815, 2003. https://doi.org/10.1890/02-3114

Herrera, H. A. R. Análise florística e fitossociológica do componente arbóreo da Floresta Ombrófila Mista presente na reserva florestal Embrapa/Epagri, Caçador, SC-Brasil. Floresta, v. 39, p. 485-500, 2009.

Hijmans, R. J.; Cameron, S. E.; Parra, J. L.; Jones, P. G.; Jarvis, A. Very high resolution interpolated climate surfaces for global land areas. International Journal of Climatology, v. 25, p. 1965-1978, 2005. https://doi.org/10.1002/joc.1276

Hijmans, R. J.; Phillips, S.; Leathwick, J.; Elith, J. DISMO: Species distribution modeling. 2017. In: R package version 1.1-4. Available from: <https://CRAN.Rproject.org/package= dismo>. Accessed on: Jan. 26, 2020.

IBGE - Instituto Brasileiro de Geografia e Estatística. Censo demográfico 2010: características da população e dos domicílios: resultados do universo. Rio de Janeiro: IBGE, 2011. Available from: <http://www.ibge.gov.br/home/estatistica/populacao/censo2010/ caracteristicas_da_populacao/resultados_do_universo.pdf>. Accessed on Jan. 26, 2020.

Jiménez-Valverde, A.; Lobo, J. M. Threshold criteria for conversion of probability of species presence to either-or presence-absence. Acta Oecologica, v. 31, no. 3, p. 361-369, 2007. https://doi.org/10.1016/j.actao.2007.02.001

Kaminski, N.; La Torre, G. M.; Barcik, J. J.; Nicola, P. A.; Pereira, L. C. M. Novas áreas de ocorrência e considerações sobre o estado de conservação do arapaçu-do-nordeste (Xiphocolaptes falcirostris) para a região central de Pernambuco, Brasil. Atualidades Ornitológicas, n. 175, 2013.

Kiill, L. H. P.; Lima, P. C. F. Plano de manejo para espécies da Caatinga ameaçadas de extinção na reserva legal do Projeto Salitre. Brasília: Embrapa, 2011. (Documentos, 243.).

Kiill, L. H. P.; Dias, C. T. V.; Souza, S. A. O. Fenologia de Schinopsis brasiliensis Engl na reserva legal do Projeto Salitre, Juazeiro-BA. Anais do 56을 Congresso Nacional de Botânica, Curitiba, 2005. 
Kumar, S.; Stohlgren, T. J. Maxent modeling for predicting suitable habitat for threatened and endangered tree Canacomyrica monticola in New Caledonia. Journal of Ecology and Natural Environment, v. 1, no. 4, p. 94-98, 2009.

Leite, A. P.; Pedrosa, K. M.; Lucena, C. M.; Carvalho, T. K. N.; Félix, L. P.; Lucena, R. F. P. Uso e conhecimento de espécies em uma comunidade rural no Vale do Piancó (Paraíba, Nordeste, Brasil). Revista de Biologia e Farmácia, v. especial, p. 133-157, 2012.

Liu, C.; White, M.; Newell, G. Selecting thresholds for the prediction of species occurrence with presence-only data. Journal of Biogeography, v. 40, p.778-789, 2013. https://doi.org/10.1111/jbi.12058

Lima, A. L. A. Padrões fenológicos de espécies lenhosas e cactáceas em uma área do semiárido do Nordeste do Brasil. Recife: Universidade Federal Rural de Pernambuco, 2007. (Dissertação de mestrado).

Lima, G. S. D.; Nobre, R. G.; Gheyi, H. R.; Soares, L. A. D. A.; Silva, A. O. Produção da mamoneira cultivada com águas salinas e doses de nitrogênio. Revista Ciência

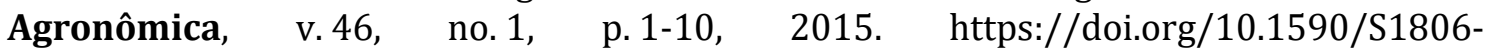
66902015000100001

Longhi, S. J. A estrutura de uma floresta natural de Araucaria angustifolia (Bert.) 0. Ktze, no sul do Brasil. Curitiba: Universidade Federal do Paraná, 2013. (Tese de doutorado).

Lorenzi, H. E.; Matos, F. J. A. Plantas medicinais no Brasil: nativas e exóticas. Nova Odessa: Instituto Plantarum, 2002.

Lucena, R. F. P.; Nascimeno, V. T.; Araújo, E. L.; Albuquerque, U. P. Local uses of native plants in an area of Caatinga vegetation (Pernambuco, NE-Brazil). Ethnobotany Research and Applications, v. 6, p. 3-13, 2008.

Lucena, C. M. D.; Lucena, R. F.; Costa, G. M.; Carvalho, T. K.; Costa, G. G.; Alves, R. R.; Pereira, D. D.; Ribeiro, J. E. S.; Alves, C. A. B.; Quirino, Z. G. M.; Nunes, E. N. Use and knowledge of Cactaceae in Northeastern Brazil. Journal of Ethnobiology and Ethnomedicine, v. 9, Article number 62, 2013. https://doi.org/10.1186/1746-4269-9-62

Lucena, R. F.; Diego, B. D. O.; Leal, J. L. D. M.; Guerra, N. M.; Leite, A. P.; Ribeiro, J. E. D. S.; Sousa, R. F. Traditional knowledge and use of Mimosa tenuiflora (Wild.) Poir. (jurema-preta) in the semi-arid region from Northeastern Brazil. Gaia Scientia, v. 8, no. 1, p. 3450, 2014.

Lucena, R. F. P.; Sousa, R. F.; Guerra, N. M.; Ribeiro, J. E. S.; Leite, A. P.; Abreu, D. B. O.; Carvalho, T. K. N.; Trovão, D. M. B. M.; Alves, C. A. B.; Alves, R. R. N.; Borges, P. F.; Andrade, L. A.; Souto, J. S. S. P.; Sousa, Jr.; Nunes, E. N. The ecological apparency hypothesis and dry tropical forests: An assessment ethnobotany. Etnoecológica, v. 10, no. 9, p. 1-17, 2014.

Lucena, R. F. P.; Medeiros, P. M.; Araújo, E. L.; Alves, A. G. C.; Albuquerque, U. P. The ecological apparency hypothesis and the importance of useful plants in rural communities from northeastern Brazil: An assessment based on use value. Journal of Environmental Management, v. 96, p. 106-115, 2012a. https://doi.org/10.1016/j.jenvman.2011.09.001

Lucena, R. F. P.; Soares, T. C.; Vasconcelos Neto, C. F. A.; Carvalho, T. K. N.; Lucena, C. M.; Alves, R. R. N. Uso de recursos vegetais da Caatinga em uma comunidade rural no Curimataú paraibano (Nordeste do Brasil). Polibotánica, v. 34, p. 217-238, 2012b. 
Luz, C. L. S.; Mitchell, J. D.; Mitchell, J. D.; Mitchell, J. D.; Mitchell, J. D.; Mitchell, J. D.; Pirani, J. R.; Pell, S. K.; Pell, S. K.; Pell, S. K.; Pell, S. K.; Pell, S. K. Anacardiaceae. In: Flora do Brasil 2020 em construção. Rio de Janeiro: Jardim Botânico do Rio de Janeiro, 2020. Available from: <http://floradobrasil.jbrj.gov.br/reflora/floradobrasil/FB4396>. Accessed on: 26 Jul. 2020.

Maia, G. N. Caatinga: árvores e arbustos e suas utilidades. 1. ed. São Paulo: D e Z Computação Gráfica e Editora, 2004.

Martins, S. S.; Couto, L.; Machado, C. C.; Souza, A. L. Efeito da exploração florestal seletiva em uma floresta estacional semidecidual. Revista Árvore, v. 27, no. 1, p. 65-70, 2003. https://doi.org/10.1590/S0100-67622003000100009

Mendes Júnior, T. C.; Drumond, M. A. Estrutura fitossociológica de um fragmento de Caatinga sensu stricto 30 anos após corte raso, Petrolina-PE, Brasil. Revista Caatinga, v. 24, n. 2, p. 67-74, 2009.

MMA - Ministério do Meio Ambiente. Brazilian forests at a glance: reference period: 2005-2009. Brasília: MMA, 2009.

MMA - Ministério do Meio Ambiente. Ministério do Meio Ambiente, dos Recursos Hídricos e da Amazônia Legal. Brasília: MMA, 2008.

MMA - Ministério do Meio Ambiente. Instrução Normativa no 06, de 23 de setembro de 2008. Available from: <http://www.ibama.gov.br/recursos-florestais/documentos/listaoficial-de-especies-brasileiras-ameacadas-de-extincao/>. Accessed on: 26 Jul. 2020.

Oyama, M. D.; Nobre, C. A. Climatic consequences of a large-scale desertification in Northeast Brazil: A GCM simulation study. Journal of Climate, v. 17, p. 3203-3213, 2004. https://doi.org/10.1175/1520-0442(2004)017<3203:CCOALD>2.0.C0;2

Pearson, R. G.; Raxworthy, C. J.; Nakamura, M.; Peterson, A. T. Predicting species distributions from small numbers of occurrence records: A test case using cryptic geckos in Madagascar. Journal of Biogeography, v. 34, no. 1, p. 102-117, 2007. https://doi.org/10.1111/j.1365-2699.2006.01594.x

Pedrosa, K. M.; Gomes, D. S.; Lucena, C. M.; Pereira, D. D.; Silvino, G. S.; Lucena, R. F. P. Uso e disponibilidade local de Sideroxylon obtusifolium (Roem. e Schult.) T.D. Penn. (quixabeira) em três regiões da Depressão Sertaneja da Paraíba, Nordeste do Brasil. BioFar, v. especial, p. 158-183, 2012.

Pereira, S. C.; Gamarra-Rojas, G.; Lima, M.; Gallindo, F. A. T. Plantas úteis do Nordeste do Brasil. Recife: Centro Nordestino de Informações sobre Plantas/Associação Plantas do Nordeste, 2003.

Phillips, S. J.; Anderson, R. P.; Schapire, R. E. Maximum entropy modeling of species geographic distributions. Ecological Modelling, v. 190, no. 3, p. 231-259, 2006. https://doi.org/10.1016/j.ecolmodel.2005.03.026

Phillips, S. J. Transferability, sample selection bias and background data in presence-only modeling: A response to Peterson et al. and (2007). Ecography, v. 31, p. 272-278, 2008. https://doi.org/10.1111/j.0906-7590.2008.5378.x

QGIS Development Team. QGIS Geographic Information System. Open Source Geospatial Foundation Project, 2018. Available from: <http://qgis.osgeo.org>. Accessed on: 26 Jul. 2020. 
Ribeiro, J. E. S.; Carvalho, T. K. N.; Ribeiro, J. P. O.; Guerra, N. M.; Silva, N.; Pedrosa, K. M.; Alves, C. A. B.; Sousa Júnior, S. P.; Souto, J. S; Nunes, A.T.; Lima, J. R. F.; Oliveira, R. S.; Lucena, R. F. P. Ecological apparency hypothesis and availability of useful plants: Testing different use values. Ethnobotany Research e Applications, v. 12, p. 415-432, 2014.

Santana, J. A. S. Padrão de distribuição e estrutura diamétrica de Croton sonderianus Muell. Arg. (marmeleiro) na Caatinga da Estação Ecológica do Seridó. Revista Verde de Agroecologia e Desenvolvimento Sustentável, v. 4, no. 3, p. 85-90, 2009.

Silva, R. M. A. Entre dois paradigmas: combate à seca e convivência com o semi-árido. Sociedade e Estado, v. 18, no. 1/2, p. 361-385, 2003. https://doi.org/10.1590/S010269922003000100017

Silva, H. C. H.; Caraciolo, R. L. F.; Marangon, L. C.; Ramos, M. A.; Santos, L. L.; Albuquerque, U. P. Evaluating different methods used in ethnobotanical and ecological studies to record plant biodiversity. Journal of Ethnobiology and Ethnomedicine, v. 10, no. 1, Article number 48, 2014. https://doi.org/10.1186/1746-4269-10-48

Silva, N.; Lucena, R. F. P.; Lima, J. R. F.; Lima, G. D. S.; Carvalho, T. K. N.; Sousa Júnior, S. P.; Alves, C. A. B. Conhecimento e uso da vegetação nativa da Caatinga em uma comunidade rural da Paraíba, Nordeste do Brasil. Boletim do Museu de Biologia Mello Leitão, v. 34, p. 5-37, 2014.

Silva, K. E.; Martins, S. V.; Santos, N. T.; Ribeiro, C. A. A. S. Padrão espacial de espécies arbóreas tropicais. In: Martins, S. V. (Ed.). Ecologia de florestas tropicais. Viçosa: UFV, 2009. p. 216-241.

Sousa, L. G. Economia, política e sociedade: a economia no semiárido. Campina Grande: 0 Autor, 2006. Available from: <http://www.eumed.net/libros/2006a/lgs-eps/>. Accessed on: Apr. 30, 2020.

Sousa, R. F.; Gomes, D. S.; Leite, A. P.; Santos, S. S., Alves, C. A. B.; Lucena, R. F. P. Estudo etnobotânico de Myracrodruon urundeuva Allemão em uma Comunidade Rural na Microrregião de Itaporanga, Paraíba, Brasil. Biofar, v. 7, no. 1, p. 1983-4209, 2012.

Souza, P. B.; Souza, A. L.; Meira Neto, J. A. A. Estrutura diamétrica dos estratos e grupos ecológicos de uma área de floresta estacional semidecidual, em Dionísio, MG. Revista

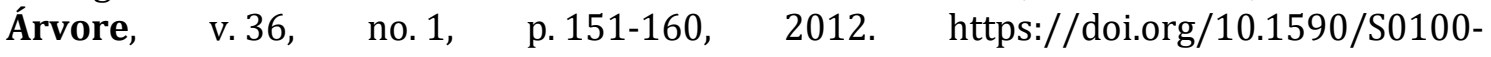
67622012000100016

Sturges, H.A. The choice of a class interval. Journal of the American Statistical Association, v. 21, no. 153, p.65-66, 1926. https://doi.org/10.1080/01621459.1926. 10502161

Swets, J. A. Measuring the accuracy of diagnostic systems. Science, v. 240, no. 4257, p. 1285-1293, 1988. https://doi.org/10.1126/science.3287615

Trovão, D. M. B. M.; Silva, S. C.; Silva, A. B.; Vieira-Júnior, R. L. Estudo comparativo entre três fisionomias de Caatinga no Estado da Paraíba e análise do uso das espécies vegetais pelo homem nas áreas de estudo. Revista de Biologia e Ciências da Terra, v. 4, no. 2, 2004.

License information: This is an open-access article distributed under the terms of the Creative Commons Attribution License, which permits unrestricted use, distribution, and reproduction in any medium, provided the original work is properly cited. 